\title{
Sporophyte morphology and gametophyte development of the fern Blechnum sprucei (Pteridophyta: Blechnaceae)
}

\author{
Jose María Gabriel y Galán ${ }^{1 *}$, Lilian M. Passarelli² ${ }^{2}$ Carmen Prada $^{1}$ \& Cristina H. Rolleri²
}

1. Departamento de Biología Vegetal I, Facultad de Ciencias Biológicas, Universidad Complutense, Ciudad Universitaria, 28040 Madrid, España.jmgabriel@bio.ucm.es; cpm@bio.ucm.es.

2. Laboratorio de Estudios de Anatomía Vegetal Evolutiva y Sistemática (LEAVES), Facultad de Ciencias Naturales y Museo de La Plata, 64 entre 120 y diagonal 113, B1904 DZB, La Plata, Argentina.

lmpassarelli@hotmail.com; tinar@speedy.com.ar.

* Correspondence: Departamento de Biología Vegetal I, Facultad de Ciencias Biológicas, Universidad Complutense de Madrid, Ciudad Universitaria, 28040 Madrid, España. Tel.: +34913945049; Fax: +34913945034; jmgabriel@bio.ucm.es

\section{Received 28-XI-2007. Corrected 30-VI-2008. Accepted 31-VII-2008.}

\begin{abstract}
The fern Blechnum sprucei grows in Mesoamerica (Costa Rica) and South America, from Colombia to Bolivia, SE and centre of Brazil, Paraguay and Argentina. It is a distinctive, somewhat vulnerable, mostly orophilous species. Fresh and dry herbarium material was used for this study. Herbarium material for anatomical studies comes from CTES, BA, LP, MA, SI and UC (Holmgren et al.1990). Selected representative specimens are additionally cited after taxonomic treatment of the species. Dry material was restored with aqueous 4:1 butil cellosolve. Pinnae were cleared with aqueous $6 \% \mathrm{NaOH}$, then coloured with aqueous $1 \%$ TBO (Gurr 1966). Hand made transverse sections of young and adult stipes, and costae were done in fresh and restored herbarium material. Venation and epidermal patterns were analyzed in basal, apical and medium pinnae, but only the latter were illustrated. The size and density of stomata were measured in medium pinnae from all studied samples, values shown are the average of 25 measures per sample; sizes are expressed as minimum, media and maximum length $\mathrm{x}$ width, in $\mu \mathrm{m}$, and density as minimum, media and maximum number of stomata $/ \mathrm{mm}^{2}$. Spores were studied with SEM, mounted on metal stubs with double sided tape, covered with gold under vacuum and photographed with a Jeol /EO JSM 6360 (15 KV) SEM. Spores were also studied with light microscope, mounted in DePeX (DePeX mounting medium, Gurr, BDH Laboratory Supplies, Poole BH15 1TD, UK) and measured using an ocular micrometer. Measurements are based on a minimum sample of 100 spores taken from different specimens. Sizes are expressed as the longest equatorial diameter/ polar diameter, in $\mu \mathrm{m}$. Gametophytes were studied from material collected in the subtropical forest of Tucumán Province, Argentina. Spore samples for cultures were taken from single sporophytes kept dry at room temperature since the date plants were collected. Gametophytes were grown under fluorescent light. Multispore cultures were established on mineral agar. Percentage of germination was recorded for a random sample of 50 spores from each of the two plates, every three days until there was no further increasing. Gametophytes were stained with chloral hydrate acetocarmine. The species has large sporophytes, suberect, scaly rhizomes, and dimorphic fronds with short, scaly stipes and lanceolate to elliptic sterile laminae. The rachises can grow indefinitely as radicant axis that vegetatively multiplicate the plants. Pinnae are lanceolate, herbaceous, with crenate and papillose margins, superficially scaly and hairy, peciolulate, with free, visible veins regularly once furcated near the costa, ending in large, active hydathodes. The broadly elliptic fertile laminae bear distant pinnae, with vegetative tissue reduced to the portion that supports the indusium and the continuous coenosorus; terminal indefinite rachis, not proliferous, may be present. Rev. Biol. Trop. 56 (4): 2027-2040. Epub 2008 December 12.
\end{abstract}

Key words: Blechnum sprucei, anatomy, distribution, gametophyte, morphology, sexual expression, spore, taxonomy. 
Blechnum sprucei C. Chr. is one of the most distinctive species of Blechnum. It has been treated in floras and catalogues, such as de la Sota (1977), Tryon and Stolze (1993), Moran (1995), Ponce (1996), Oliveira Dittrich (2005), and Rolleri and Prada (2006a), but the descriptions are superficial, sometimes incomplete, and the morphological characters are not well known. This species was never compared with others supposedly related, and the spores and gametophyte development were unknown.

Blechnum sprucei was considered by Tryon and Tryon (1982) to belong to B. lineatum (Sw.) C. Chr. group, which includes large plants, with massive decumbent, slightly creeping or semiscandent rhizomes, and dimorphic fronds, together with other 15-20 species, such as B. cordatum (Desv.) Hieron., B. chilense (Kaulf.) Mett., B. chiriquanum (Broadh.) C. Chr., B. costaricense (Broadh.) C. Chr., B. divergens (Kunze) Mett., B. lehmanii Hieron., B. Iherminieri (Bory) C. Chr., B. lineatum (Sw.) C. Chr., B. pteropus (Kunze) Mett., and B. varians (Fourn.) C. Chr. The taxa with petiolulate pinnae, lamina and axis with abundant indument, and bulbils or aerophores in the raquis, were separated from the $B$. lineatum group by Oliveira Dittrich (2005), in the new B. cordatum group, in which B. sprucei was placed.

Rolleri and Prada (2006b) suggested that some of the groups established by Tryon and Tryon (1982) in Blechnum are quite restrictive, and had been defined using fairly few characters. The B. lineatum group is clearly artificial, and encompasses a number of not well known species which should be analyzed before considering the mere existence of the group as currently defined (Prada et al. 2008, Rolleri et al. 2008).

Blechnum sprucei was studied from specimens of its large geographical area. The following characters of the sporophyte have been considered: rhizome, rhizomatic scales, size, outline and division of laminae, outline, size, texture, margins, venation patterns, epidermal patterns, stomata, and ontogeny of epidermis and stomata of pinnae, internal morphology of stipes, number of vascular bundles in young and adult axis, mesophyll and distribution of mechanical tissue (fibers) on costae.

For the first time, the morphology and germination of spores, the development of the gametophytic generation, and its sexual expression were also studied.

Based on the investigation made, a comprehensive biological revision of $B$. sprucei is presented here, with an updated description of the species, as well as comments on its affinities, ecology and geographical distribution.

\section{MATERIAL AND METHODS}

Fresh and dry herbarium material was used for this study. Herbarium material for anatomical studies comes from CTES, BA, LP, MA, SI and UC (Holmgren et al.1990). Selected representative specimens are additionally cited after taxonomic treatment of the species.

Dry material was restored with aqueous 4:1 butil cellosolve. Pinnae were cleared with aqueous $6 \% \mathrm{NaOH}$, then coloured with aqueous $1 \%$ TBO (Gurr 1966). Hand made transverse sections of young and adult stipes, and costae were done in fresh and restored herbarium material. Venation and epidermal patterns were analyzed in basal, apical and medium pinnae, but only the latter were illustrated. The size and density of stomata were measured in medium pinnae from all studied samples, values shown are the average of 25 measures per sample; sizes are expressed as minimum, media and maximum length $\mathrm{x}$ width, in $\mu \mathrm{m}$, and density as minimum, media and maximum number of stomata $/ \mathrm{mm}^{2}$.

Spores were studied with SEM, mounted on metal stubs with double sided tape, covered with gold under vacuum and photographed with a Jeol /EO JSM 6360 (15 KV) SEM. Spores were also studied with light microscope, mounted in DePeX (DePeX mounting medium, Gurr, BDH Laboratory Supplies, Poole BH15 1TD, UK) and measured using an ocular micrometer. Measurements are based on a minimum sample of 100 spores taken from different specimens. Sizes are expressed as the longest equatorial diameter/ polar diameter, in $\mu \mathrm{m}$. 
Gametophytes were studied from material collected in the subtropical forest of Tucumán Province, Argentina, by one of the authors. Spore samples for cultures were taken from single sporophytes kept dry at room temperature since the date plants were collected. Gametophytes were grown under fluorescent light on a 12-h light, 12-h dark cycle at $20 \pm$ $2^{\circ} \mathrm{C}$, in plastic Petri dishes $6 \mathrm{~cm}$ in diameter. Multispore cultures on mineral agar medium (Dyer 1979) were established by sacking fertile pinnae on a weigh paper, and placing the obtained spores in the Petri dishes. The sowing was replicated twice for each sample. Percentage of germination was recorded for a random sample of 50 spores from each of the two plates, every three days until there was no further increasing. To study the stages of gametophyte development, random samples were taken weekly, from the beginning of spore germination until sexual maturity. Gametophytes were stained with chloral hydrate acetocarmine (Edwards and Miller 1972), mounted in water and observed under a light microscope.

General terminology comes from Lellinger (2002); epidermal terms can be found in Prabhakar (2003), Rolleri (2004) and Rolleri and Prada (2006b). The terms related to spores are in Lellinger and Taylor (1997) and Passarelli (2007).

\section{RESULTS}

Sporophyte and spores. Blechnum sprucei have large, non arborescent sporophytes. Rhizomes are suberect to procumbent or scandent, sometimes short-creeping, rigid, densely scaly.

Fronds are strongly dimorphic (Fig. 1A-C, $\mathrm{G})$, both sterile and fertile 1-pinnate, the fertile usually shorter. Stipes are short, stiff in adult plants, adaxially canaliculated, moderate to densely scaly with scales similar to those of rhizome (Fig. 1D, E-F). Rachises are scaly, papillate, with occasional aerophores in the base of pinnae.

Sterile laminae are lanceolate to elliptic-lanceolate, pinnate. The base is cuneate, attenuate, and has aphlebiae all along the stipe, reaching the rhizome. The apices are acute or largely prolonged in a radicant axis. The two apices types appear in different fronds of the same plant. Lamina is intense green in adaxial surface, lighter in the abaxial, dully, firmly herbaceous in texture, rarely subcoriaceus in very large plants. Pinnae are present in a variable number of pairs depending on the plant age and on the presence of a proliferous apex (Fig. 1A-C, 3A). Costae are quite prominent, adaxially sulcate, rather curved abaxially, moderately scaly, and densely pilose.

The laminae with acute apices have a terminal pinna, lanceate to lanceolate, similar to the lateral ones or quite shorter, with tapering acuminate apex, enlarged base, auriculate or irregularly expanded, lacerate or incised in one of the hemiphylls. These fronds bear 25-30 pairs of lateral pinnae, the middle ones $4-8 \mathrm{~cm}$ length $\times 1-2 \mathrm{~cm}$ width, lanceolate to triangularlanceolate in outline, almost horizontal, contiguous to imbricate, briefly petiolulate, with an acute apex, a symmetric or somewhat asymmetric base, often auriculate and overlapping the rachis, with crenate papillose margins.

The laminae with extended rachises have undefined growth, bear pinnae gradually reduced toward the apex which is proliferous, generating distal plantlets that quickly produce roots, and detach easily to generate new individuals. There are up to 70-80 pinna pairs, 18-30 well developed pairs with sizes as indicated above, 10 or more basal pairs gradually reduced, and 30 or more apical also reduced pairs (Figs. 1A, 2J-M).

Margin of pinnae are plane, regularly undulate, and papillate with 1-3 rows of conical, approximate, moderately thickened papillae found all along the margins, continuous, sometimes more densely concentrated in the salient of the undulations than in sinuses (Fig. 2A, C).

Venation is free, with visible veins regularly bifurcate at similar distances from the costa, ending in large hydathodes, not prominent but evident, mostly located in the margin sinuses (Fig. 2A, J-M). 


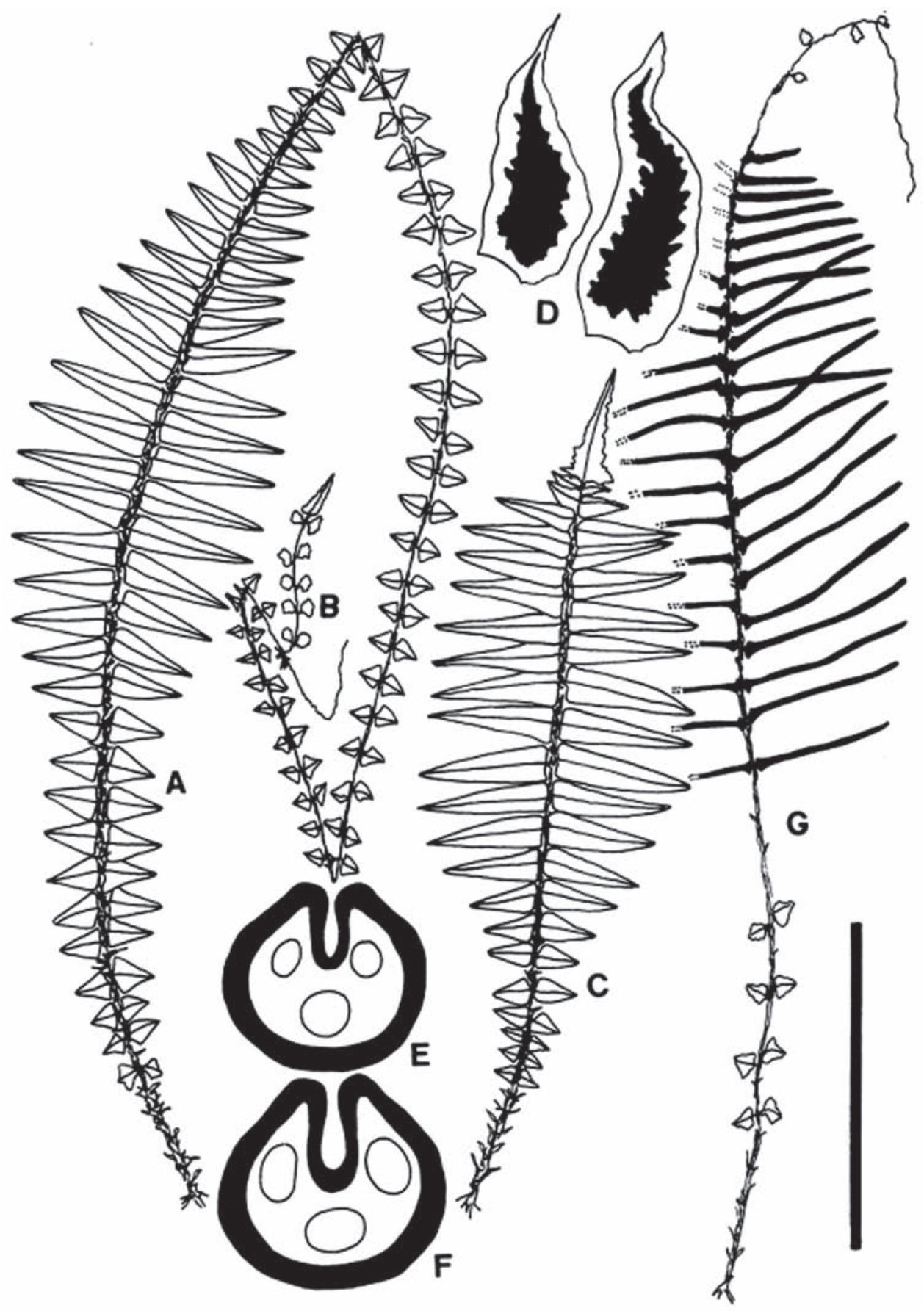

Fig. 1. Sterile and fertile fronds of B. sprucei. A: Frond with proliferous rachis. B: Plantlet growing vegetatively at the elongated, proliferous rachis. C: Non proliferous frond with terminal pinna. D: Two rhizomatic scales. E: Transversal sections of stipe in A. F: Transversal section of stipe in C and G. G: Fertile frond. Bar: $20 \mathrm{~cm}$ in A, C, G; 1,5 cm in D; 0,5 cm in E-F. 


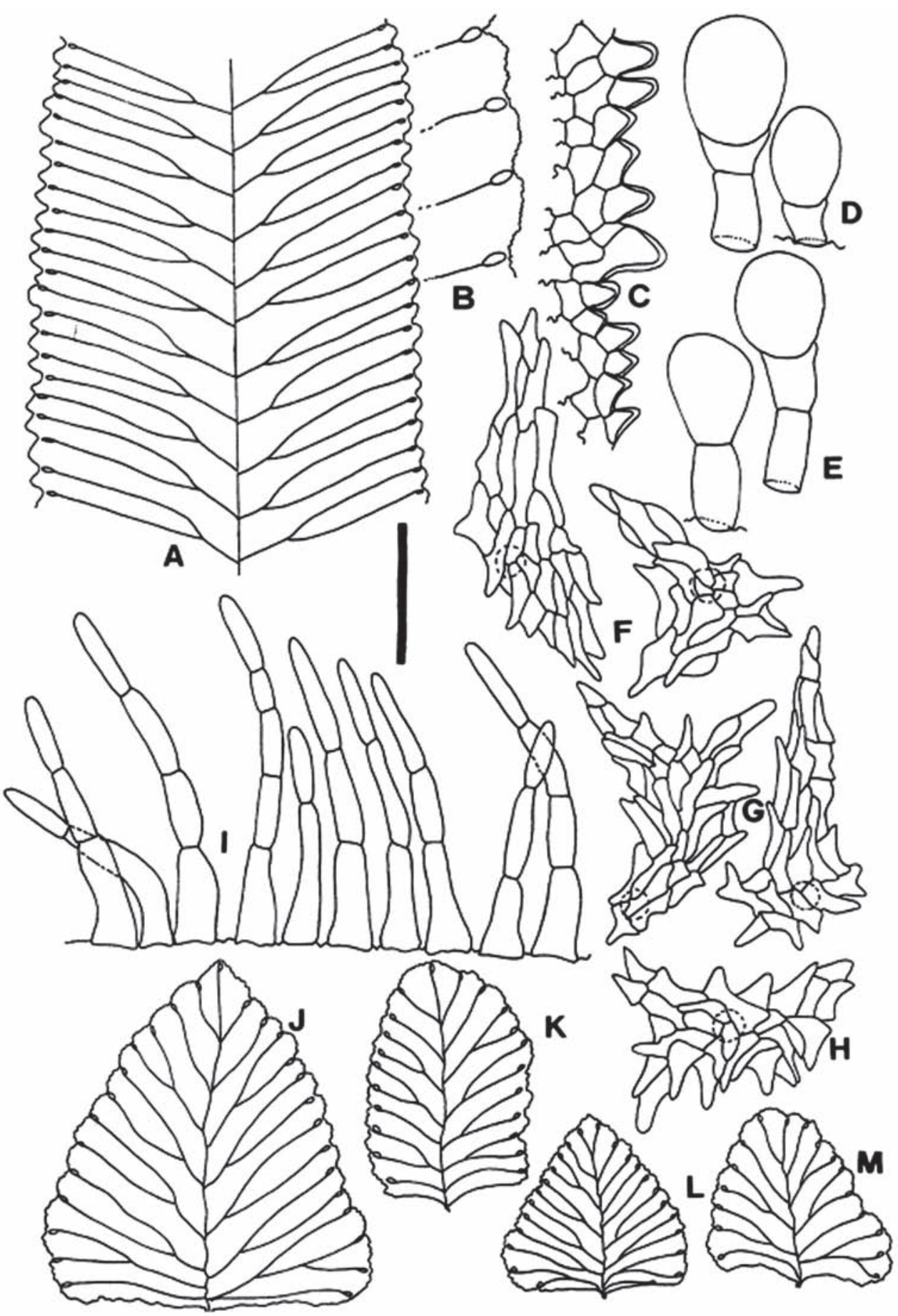

Fig. 2. Venation and indument in fronds of B. sprucei. A: Venation of an adult, middle pinna. B-C: Margin of an adult, middle pinna. B: Schema in A. C: Detail of the papillate margin. D-E: Glandular, capitate hairs. F-H: Stellate, peltate scales. I: Uniseriate, eglandular hairs. J: Reduced pinnae from the base of frond. K-M: Reduced pinna from the proliferous rachis. Bar: $0,5 \mathrm{~cm}$ in $\mathrm{A} ; 0,1 \mathrm{~cm}$ in $\mathrm{B} ; 100 \mu \mathrm{m}$ in $\mathrm{C} ; 200 \mu \mathrm{m}$ in D-I; $1,5 \mathrm{~cm}$ in $\mathrm{J}-\mathrm{M}$. 
Plantlets have a very short, up to $0,3 \mathrm{~cm}$ stipe, a comparatively large apical pinna with quite asymmetric cordate base; 4-10 pairs of juvenile pinnae are rapidly formed, with nearly circular outline and an appearance of aphlebiae (Fig. 3A, C-G).

Indument is represented by hairs and scales. The following variation was found: In rhizomes and stipes, scales are 0.5-2.5 x 0.2$0.3 \mathrm{~cm}$, light brown, with a translucent entire margin, and a dark, unistratified or 2-3 layers thick central band, lanceolate, basifixed, with rounded base and acute to largely attenuate apex (Fig. 1D).

In rachises, costae and laminae scales and hairs are present (Fig. 2 D-I). Scales predominate in rachises and costae, are sparse in veins, and almost absent in laminae. Scales are peltate, with a 1-cellular base, an irregular to stellate body with divergent arms that end in blunt or acute cells. Hairs are eglandular and glandular, uniseriate. Eglandular hairs are formed by 2-5(7) cylindrical cells, with elongated cylindrical base and narrow apical cell; these hairs are abundant in all axes, especially in the costae. Glandular hairs have a 1-2 cellular body and a big capitate, mucilaginiferous gland, spherical or ellipsoidal. Eglandular hairs are more abundant than glandular, the latter disperse only in veins and laminae.

Epidermal patterns are sinuous in epiphylls and hypophylls, and the epidermal cells have thin walls. The ontogeny of epidermis as seen in plantlets showed a subpolygonal initial pattern in the terminal pinna. The epidermis mature basipetally, and juvenile subcircular basal pinnae of plantlets with 6-8 pairs of pinnae have the adult epidermal pattern already formed (Fig. 3H-N). Epiphylls and hypophylls differ in their adult epidermal patterns: epiphylls have larger cells, nearly isodiametric, sinuous to sinuous-angulose walls, with stellate appearance, whereas hypophylls have cells 2-3 times longer than wide, with irregular undulations, shallow and deep, angulose or curve (Fig. 3P-Q). Margins of both juvenile and adult pinnae are very alike, but juvenile pinnae usually have just one row of conical papillae with thinner walls than in the adults (Fig. 30).

Stomata are elliptic in outline, slightly raised over the epidermis level. Anomocytic and diacytic types predominate in adult pinnae, while diacytic type is more common in juvenile stages (Fig. 3). Adult stomata are (42) 47 (51) $\mu \mathrm{m} \mathrm{x}$ (23) 28 (31) $\mu \mathrm{m}$, and distribute with a density of (8) $10(12) / \mathrm{mm}^{2}$. Ontogeny indicates a mesoperigenous development of stomata: the stomata initial gives origin to a cell which divides to form the guard cells, and a neighboring cell that surrounds the adult stomata in the typical diacytic model. Guard cells are early developed and stomata are fully functional before adult epidermal pattern is completely formed.

In the transversal sections of young stipes the following tissues are present: a papillate, epidermis with external walls slightly thickened, a hypodermic fibrose zone, 4-5 layers thick; and a non-amylaceous, internal parenchymatic tissue which includes the leaf trace. Sequential sections of stipe in plantlets have a leaf trace formed by 2-3 vascular strands (Fig. 3B). In adult plants, stipes are nearly circular in section, adaxially sulcate, with one deep groove, and abaxially rounded; below the epidermis there is a wide hypodermic zone of fibers, 8-10 layers thick and a leaf trace with 3 strands included in a massive parenchymatic central area (Fig. 1E-F).

In the transversal sections of pinnae, the following tissues are present: an epidermis with the outer walls of the epidermal cells slightly thickened, somewhat raised stomata, and a simple, mostly homogeneous mesophyll in the lamina. At the costa, there is a central, parenchymatose area, surrounded by an endodermis with Casparian strips, with conducting tissues; xylem assumes the shape of an open V, and scarce phloem develops at the ends of the xylem arms. Compact parenchymatose tissue of large cells and groups or layers of fibers lying under abaxial and adaxial epidermis of the costa are found outside the vascular strand. No mucilage ducts were observed.

Fertile fronds are wide lanceolate or lanceate, with longer stipes than sterile ones; 


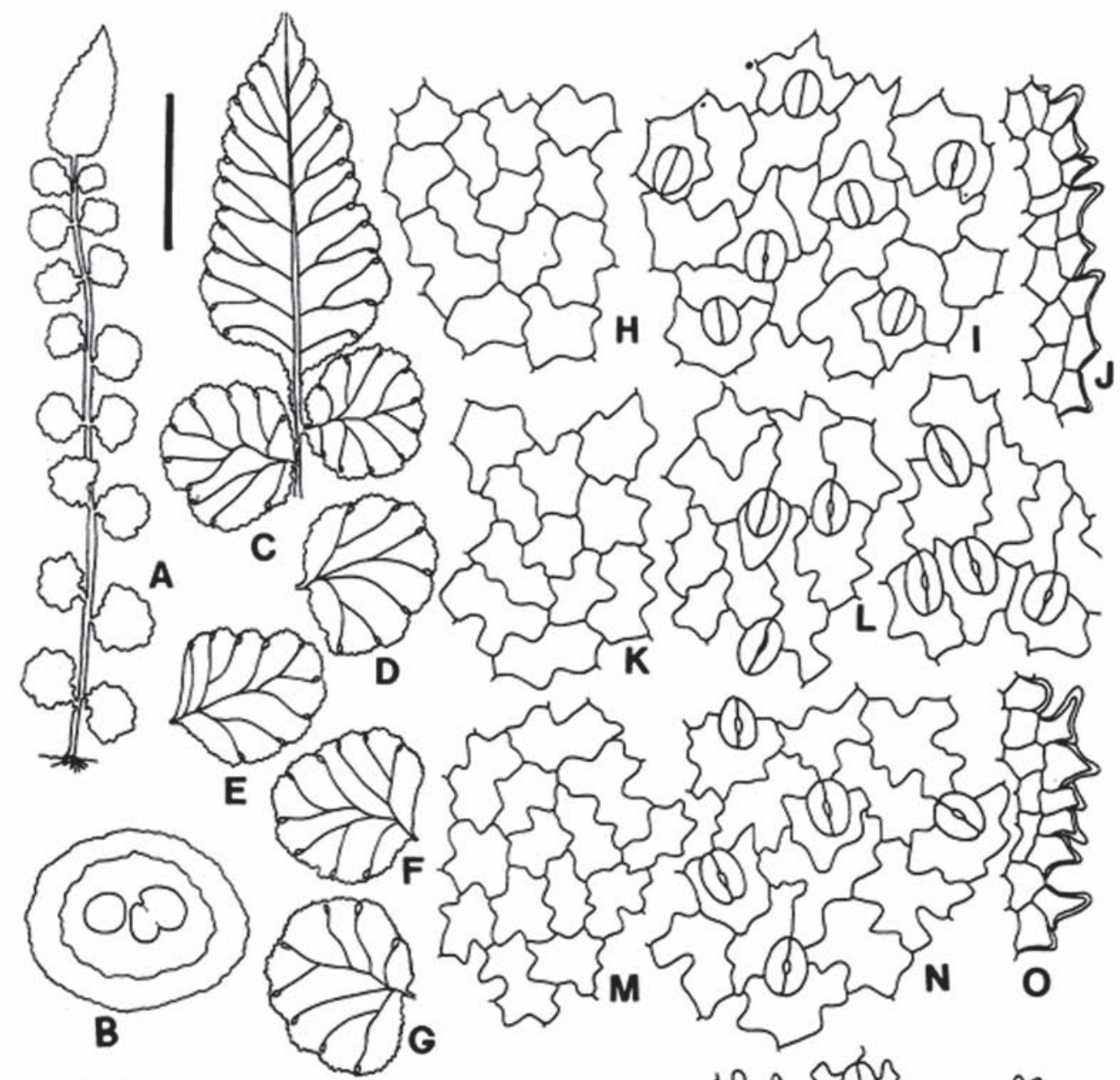

son

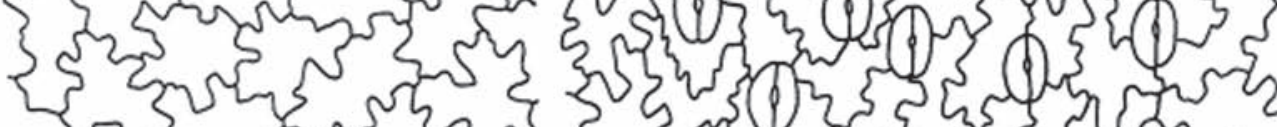

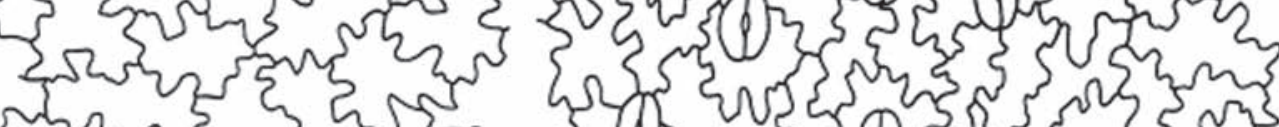
री जु s

Fig. 3. Ontogeny of epidermis in B. sprucei. A: A whole plantlet with seven pinna pairs. B: Transversal section of the juvenile stipe, with two vascular strands, one branching to form a third one. C: Terminal and first apical pinna pair of the plantlet. D-G: Middle and basal pairs of pinnae of the plantlet (basipetally illustrated). H-J: Epidermis and margin in C. K-L: Epidermis in D. M-O: Epidermis and margin in F. P-Q: Epidermis in G (similar, in adult middle pinnae). Epiphylls at the left, hipophylls at the right. Bar: $3 \mathrm{~cm}$ in A; $0,2 \mathrm{~cm}$ in B; $0,5 \mathrm{~cm}$ in $\mathrm{C}-\mathrm{G} ; 100 \mu \mathrm{m}$ in $\mathrm{H}-\mathrm{Q}$. 
they often bear distant basal aphlebiae, not always paired. It is common the presence of an apical prolongation, not radicant, of the fertile rachis, with minute aphlebiae (Fig 1G). Fertile pinnae are linear, 5-6 x $0.3 \mathrm{~cm}$, with extremely reduced laminae and auriculate bases. The indusium is continuous, with an undulated margin and their cells show a polygonal pattern with regularly thickened walls.

Spores are monolete, yellowish brown with the wall always darker than the spore body, ellipsoidal in polar view, and planconvex in equatorial view (Fig. 4). Size is (29) 34 (44) $\mathrm{x}$ (21) $25(30) \mu \mathrm{m}$, and the long-short diameters relation is less than 1.36. Sporoderm is 4 $\mu \mathrm{m}$ thick, formed by perispore and exospore. Perispore is microrugulate with rugulae homogenously distributed; it is adhered to exospore in young spores but tends to detach; detaching usually begins at the laesure zone in mature spores. Perispore presents three layers: an external, compact layer, an intermediate layer with alveolar structure and interlaced pillars, and an internal micro-granular layer, adhered to exospore. Complete perispore is $2 \mu \mathrm{m}$ thick. Exospore is psilate. Laesure reaches $2 / 3$ of the proximal face of spore, measures (12) 16 (18) $\mu \mathrm{m}$ and slightly protrudes like a curved edge, variable among spores of the same specimen.

Gametophyte development. Spores germinate during the first week after sowing (germination reached $92 \%$ ). First division produces a rhizoid and a prothallial cell which cut perpendicularly (Fig. 5). During subsequent gametophyte development the primary prothallial cell experiments some elongation, as so does the rhizoid, before undergoing the first transversal division. During the second week after sowing, the large cell divides to form a filamentous prothallus of 4-5 cells, while new rhizoids emerge. Three weeks after sowing, laminar growth begins by longitudinal divisions of the apical cells, producing wide spatulate prothalli. Later, middle apical cell divides to generate a meristematic zone, slightly lateral in position, and because of this, prothalli become clearly asymmetric. To this stage prothalli are naked, but when meristematic activity begins, marginal and superficial hairs are densely formed. Finally, by successive meristematic divisions, prothalli acquire their symmetric shape. Up to this stage, remains of spore wall are still attached to the rhizoidal pole of prothallus.

By the eleventh week from sowing, adult cordate, hairy prothalli were found. Marginal hairs are 1(2) cellular, up to $50 \mu \mathrm{m}$ long, the 2-cellular with a small basal cell, and a somewhat capitate apical cell. The 1-cellular type of hair predominates, distributed over the entire surface of the lamina.

Sexual expression begins in B. sprucei with the appearance of archegonia, a fact that represent an uncommon pattern in the gametangial development. Eleven weeks age prothalli develop archegonia, while no antheridia are formed at all. These female prothalli are cordate and vigorous. Archegonia emerged in the midrib, between the rhizoids and the meristem. Male prothalli appear increasingly in the cultures as the sterile ones tend to disappear. The male gametophytes are irregular or spatulate in shape, and are less vigorous than female ones. Antheridia are formed over the suface or, occasionally, in the margins. Only the largest male prothalli produce antheridia in the rhizoid area, while antheridia can occur all over surface in the smallest ones. Bisexual prothalli become gradually more abundant while decrease the female ones. These gametophytes have shape and size similar to the female prothalli, but male and female gametangia are originated together in the midrib area.

\section{Taxonomic treatment}

Blechnum sprucei C. Chr., Index filic.: 160. 1905, nom. nov. for Lomaria caudata Baker in Hook. \& Baker, Syn. filic.: 179. 1868, nom. illeg. non Blechnum caudatum Cav. 1805. Protologue: Hab. Andes of Ecuador, Spruce 5329. Type: Ecuador, Tunguragua, Spruce 5329 (Holotype K!, fragm. B!, photo US, isotype $\mathrm{P} !)$.

Plants terrestrial or lithophytic, large, up $160-180 \mathrm{~cm}$ tall, with suberect to procumbent, 


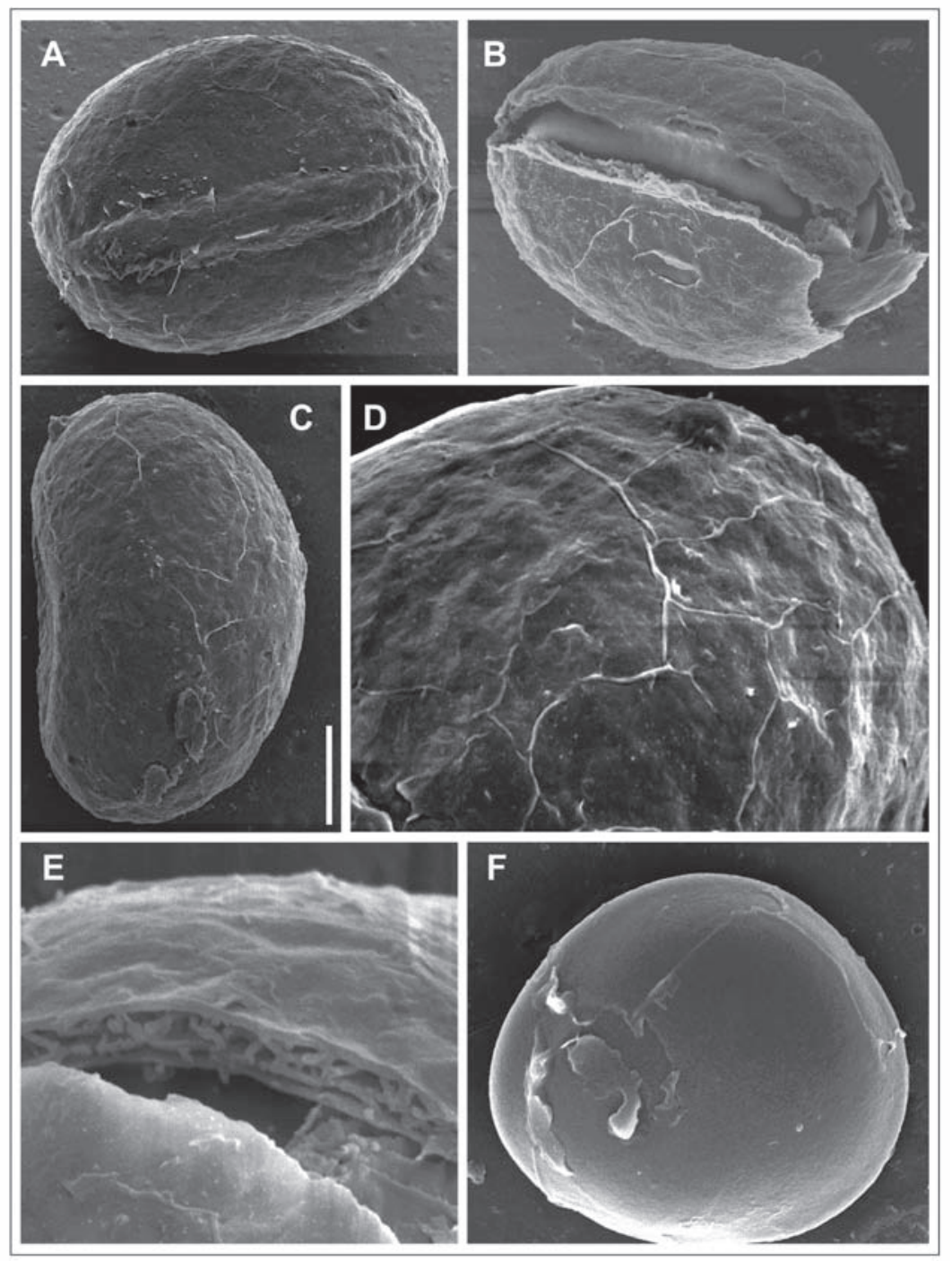

Fig. 4. Spore of B. sprucei. A: Proximal view, with rugulate perispore and protruding laesure. B: Spore with perispore detaching from laesura. C: Lateral view of a spore with perispore. D: Rugulate to venulosoe-rugulate surface of the perispore. E: Perispore in transversal section. F: Exospore. Bar: $10 \mu \mathrm{m}$ in A-C, F; $20 \mu \mathrm{m}$ in D; $5 \mu \mathrm{m}$ in E.

not arborescent, sometimes short-creeping, rigid, scaly rhizomes, without stolons. Rhizome scales entire, lanceolate, up to $1.5 \mathrm{~cm}$ long x 0.3 $\mathrm{cm}$ wide, discolor, light brown with or without a dark central area and translucent, smooth or repand margins. Fronds strongly dimorphic, 1-pinnate. Stipes short, 20-25 (39) cm, stiff in adult plants, adaxially canaliculated, moderate to densely scaly, scales similar to those of rhizome; adult stipes nearly circular in section, with one deep groove, papillate epidermis, hypodermic zone of fibers 8-10 layers thick, leaf trace with 3 vascular strands. Rachises scaly, papillate, aerophores occasional in the base of pinnae. Sterile laminae lanceolate to elliptic-lanceolate, up to $130-140 \mathrm{~cm}$, pinnate, herbaceous in texture, base cuneate, attenuate, having aphlebiae along the stipe, apex acute 


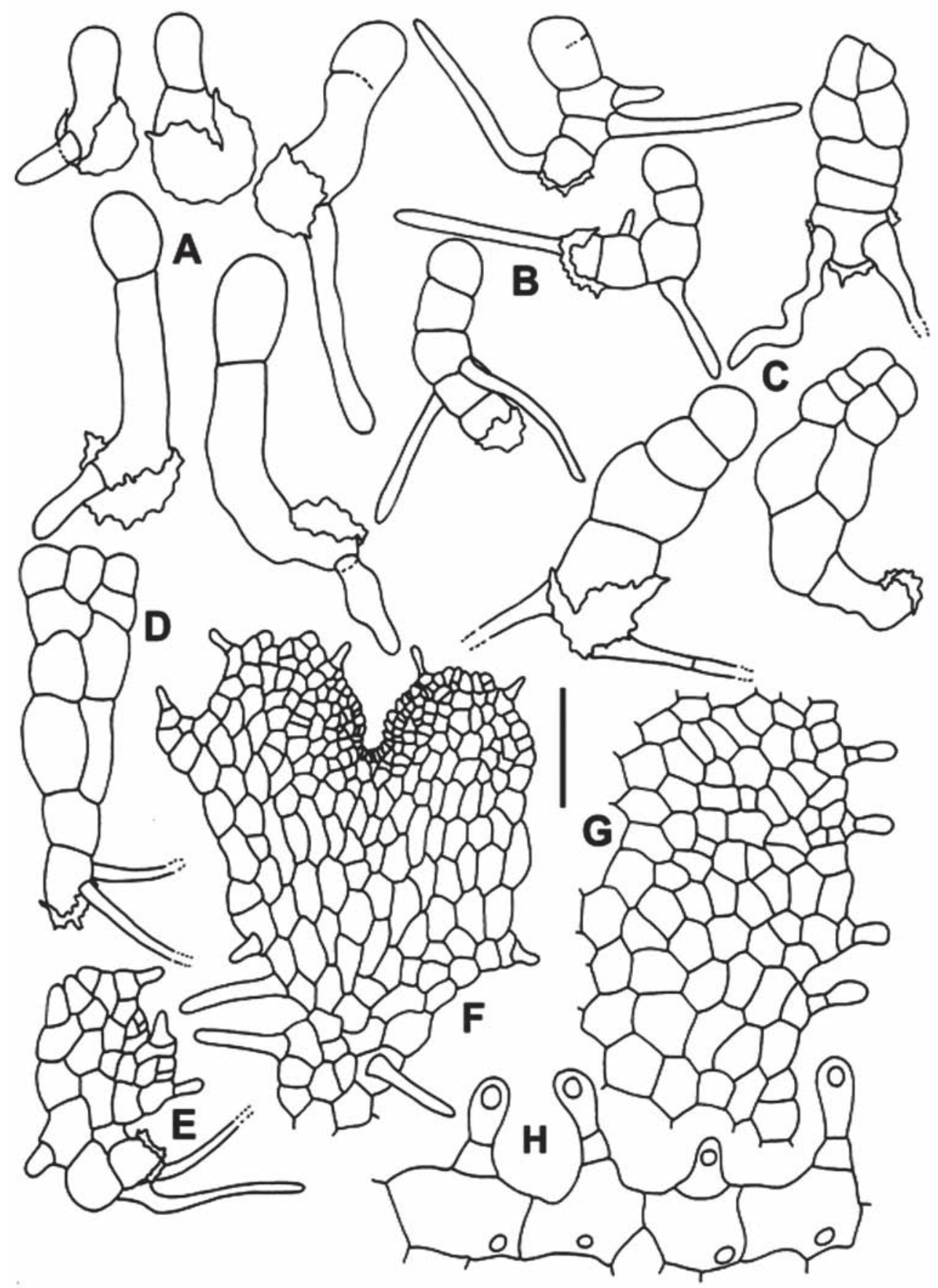

Fig. 5. Gametophyte development in B. sprucei. A: Germination of spore and elongation of prothallial cell and rhizoid (1 week). B: Formation of the 4-5 cell filaments ( 2 weeks). C: Transversal divisions and beginning of laminar growth (3 weeks). D: Spatulate prothallus (4 weeks). E: Formation of lateral meristem (4 weeks). F-H: Presexual adult gametophyte and details of marginal hairs (11 weeks). Bar: $50 \mu \mathrm{m}$ in A, H; $80 \mu \mathrm{m}$ in B; $150 \mu \mathrm{m}$ in $\mathrm{C}, \mathrm{D} ; 500 \mu \mathrm{m}$ in E, F; $100 \mu \mathrm{m}$ in G. 
or largely prolonged in a radicant axis, both types of apices appear in different fronds of the same plant. When present, apical pinna is lanceate, with attenuate apex, enlarged base, often incised, divided or lacerated; lateral pinnae 25-30 (35) pairs, 4-8 cm long x 1-2 cm wide, lanceolate to triangular-lanceolate, almost horizontal, contiguous to imbricate, briefly petiolulate, with an acute apex, a symmetric or asymmetric base, often auriculate and overlapping the rachis, crenate and subtly serrulate, papillate margins. When extended rachises are present, laminae have undefined growth and pinnae are gradually reduced toward the proliferous apex which generates distal plantlets quickly producing roots and generating new individuals; pinnae pairs up to $70-80,18-30$ with sizes as indicated above, 10-12 (14) basal pairs gradually reduced, 30 or more apical reduced pairs. Costae prominulous, adaxially sulcate, rather curved abaxially, moderately scaly, densely pilose. Venation free, veins visible, regularly bifurcate at similar distances from the costa, ending in large hydathodes. Superficial indument of scales and hairs, the scales on rachises, costae, and veins, absent in laminae. Hairs uniseriate, eglandular and glandular, the latter only on veins and laminae. Sinuous epidermal patterns both in the epiphylls and hypophylls, epidermal cells with thin walls; anomocytic and diacytic, elliptic adult stomata. Fertile fronds wide lanceolate or lanceate, stipes longer than in sterile ones, with distant basal aphlebiae, and also an apical prolongation, not radicant, with minute aphlebiae; fertile pinnae linear, 5-6 x $0.3 \mathrm{~cm}$, with extremely reduced laminae and auriculate base. Cenosorus continuous, indusium with undulated margins, and polygonal epidermal pattern of thickened cell walls. Spores monolete, ellipsoidal, light brown, (29) 34 (44) x (21) 25 (30) $\mu \mathrm{m}$; sporoderm $4 \mu \mathrm{m}$ thick, perispore rugulate, $2 \mu \mathrm{m}$ thick, with a compact external layer, an alveolar intermediate layer, and a micro-granular internal layer strongly adhered to exospore in young spores, easily detaching in the adult ones; exospore psilate; laesura (12) 16 (18) $\mu \mathrm{m}$, slightly protruding. Adult gametophytes cordate and hairy.
Geographical distribution and habitat. Costa Rica, Panamá, Colombia, Perú, Ecuador, Bolivia, SE and centre of Brasil, NW of Argentina (Jujuy, Salta, Catamarca and Tucumán Provinces). Tropical and subtropical humid cloud forests and disturbed forests, either in shallow soils or on rocky slopes, and roadsides. Plants need moderately unexposed locations with regular degree of environmental humidity. From 1500 to $3800 \mathrm{~m}$ altitude.

\section{Selected specimens}

ARGENTINA: Catamarca: Andalgalá, Esquina Grande, Jörgensen 1494 (SI). Jujuy: Ledesma, Calilegua, camino entre Mesada y Abra de Las Cañas, Brown 1719 (CTES, SI). Ledesma, Abra de Las Cañas, de la Sota 4451 (LP, US). Depto Manuel Belgrano (Capital), El Cucho, Cerro Labrado, Potrero de Las Mulas, de la Sota 4366 (LP). Salta: Santa Victoria, Los Toldos, Finca El Nogalar, 1650 m, Cassá et al. 234 (LP). Los Toldos, camino de Los Toldos a Lipeo, desvío a San José, 1750 m, Cassá et al. 285 (LP). Tucumán: Tafí, Tafí del Valle, La Casita, Castillón 13669 (LP, SI). Chicligasta, Puesto Santa Rosa, 1050 m, Meyer 15421 (LP). Tafí, carretera de Tafí del Valle, El Nogalar, 1500 m, Prada \& Gallardo s.n (MA; material used for gametophyte studies). Chicligasta, Sierra de Aconquija, subida a Las Banderitas, 1400 m, Prada \& Gallardo s.n (MA; material used for gametophyte studies). Sierra San Javier, Capurro 135 (BA).

BOLIVIA: Chuquisaca: Base oriental del Cerro Bufete, 2000 m, Arroyo et al. 913 (UC). En el lado norte del Cerro Bufete, 19002050 m, Serrano et al. 1269 (UC). 1 km de Nuevo Mundo a Padilla, 2100 m, Kessler et al. 5134 (UC). $5 \mathrm{~km}$ pasando Nuevo Mundo, 2300 m, Kessler et al. 26 (UC). Cochabamba: Aduana Alta, Colomi, 12.000 feet, Balls B6267 (UC). Pasando la represa de Corani, $3240 \mathrm{~m}$, Jiménez \& Moguer 1743 (UC). 104 km antigua carretera Cochabamba-Villa Tunari, $3150 \mathrm{~m}$, Kessler et al. 6688 (UC). Cejaregún, LlantasAduana, 3100 m, Steinbach 9525 (UC). Santa 
Cruz: Manuel M. Caballero, 2476 m, R. Nuñez 571 (UC). $13 \mathrm{~km}$ de Loma Larga a Valle Grande, 2300 m, Kessler et al. 6480 (UC). Tarija: Campamento Alisos, Río Escalera, al inicio de la senda al Nogal, 1860 m, Jiménez \& Serrano 2387 (UC).

COSTA RICA: Alajuela: Cordillera Volcánica Central, Faldas del Cerro Chayote, Pacífica Rojas 6190 (CR). Heredia: Cordillera Volcánica Central, Volcan Barba Station, path and forest between park office and crate, Forest 15-25 m, Pacifica Rojas 3556 (UC). Cordillera Volcán Central, falda W del Cerro Chompipe, Alto del Roble, Pacifica Rojas 3924 (CR).

ECUADOR: Cotopaxi: En la cima del Cerro Azul, $3681 \mathrm{~m}$, Ramos et al. 6670 (UC). Morona-Santiago: Parque Nacional Sangay, along road between Riobamba and Macas, $8 \mathrm{~km}$ east of guard house for park near Chimborazo province, $2710 \mathrm{~m}$, Croat et al. 86281 (UC). Trail Alao-Huamboya, around and above El Placer, 2850-3400 m, Øllgaard et al. 38451 (UC). Pichincha: Carretera Quito-Sto. Domingo, $2500 \mathrm{~m}$, van der Werff \& Palacios 9601 (UC). Cerro El Castillo-Loma la Bola, 2700 m, Freire et al. 3247 (UC). Corazón Peak (n. slope) and Corazón Pass (w. side), 2800 m, Ewan 16416 (UC).

\section{DISCUSSION}

Blechnum sprucei distinguishes by the presence of long radicant rachises, which allow the plant to reproduce vegetatively, a sporophytic character mostly preferred when the species is treated or included in keys. However, vegetative reproduction is not uncommon in Blechnum: several species of $B$. penna-marina (Poir.) Kuhn group are stoloniferous, B. asperum (Klotsch) Mett. produces radicant aphlebic axes (Rolleri and Prada 2006 b), and B. proliferum Rosenst. produces gemmae or bulbils along the rachis, at the base of the pinnae. The radicant apex of $B$. sprucei is just another expression of this ability.

Other diagnostic traits can be added to characterize the species, such as the diversity of the indument of axes and laminae, the venation and morphology of pinna margins, the morphology of spores, and the adult cordate, hairy gametophytes. Endomorphological characters, such as the epidermal pattern of pinnae are close to those in B. cordatum (Desv.) Hieron. (Prada et al. 2008) and B. proliferum. (Prada and Rolleri unpublished data), which points to affinities of the species with these two and others of the so-called B. cordatum group (Oliveira Dittrich 2005).

The epidermis of the indusium is a poorly studied character in species of Blechnum, but it can bring specific information (Rolleri and Prada 2006b); in the case of B. sprucei it is formed by cells with thickened walls, in a polygonal pattern, different of the indusia described for other species of the genus (Prada and Rolleri 2006b, and unpublished data).

Spores, here studied for the first time, may also bring specific characters in Blechnum, a genus which spores are scarcely studied. Spores of $B$. spruce $i$ have a venulose, rugulate perispore close to the type shown by species of the $B$. penna-marina group (Rolleri and Prada 2006b; Passarelli 2007), B. brasiliense Desv. (Rolleri and Prada, unpublished data), and a similar structure of the perispore is also known for B. magellanicum (Desv.) Mett. (Rolleri et al. 2008).

Other character to take into consideration is the vascular organization of stipes and costae, about which there are not references in the literature, at least in relation with groups of species. Stipes of all species of $B$. penna-marina group have 3 vascular strands (Rolleri and Prada 2006b), and the same organization has been observed in species of the B. occidentale L. group (Rolleri and Prada, unpublished data), similar to that described here for B. sprucei. Blechnum cordatum has multiple leaf trace stipes, with 14-16 vascular strands in adult stages, but plantlets iniciate with 3 vascular strands only, and the number of strands increases with age (Prada et al. 2008). Blechnum loxense (Kunth) Hook. ex Salomon, B. magellanicum, B. spannagelii Rosenst. and B. tabulare (Thunb.) Kuhn. have multiple leaf 
trace stipes also, but their organization differs from the $B$. cordatum type by the presence of 2-3 large, adaxial strands, and 5-7 small, abaxial ones (Rolleri et al. 2008, and unpublished data). Costae may have 3-4 strands, each one with a well developed endodermis, such as in $B$. columbiense Hieron., dictyostelic organization, such as in B. proliferum (Prada and Rolleri, unpublished data), or a central area, as the one described here for B. sprucei, with vascular tissues centered and surrounded by an endodermis with Casparian strips, with the xylem seen in transversal section as an open $\mathrm{V}$ of long arms, at the end of which a small amount of phloem is formed, a type also found in B. cycadifolium (Colla) Sturm, B. magellanicum, B.spannagelii, B. schomburgkii (Klotzsch) C. Chr. and B. tabulare. Disposition of mechanical tissues varies among all aforementioned species, and fibers can occur as hypodermal, abaxial and adaxial groups, or as a large area that covers all the costa, and goes from the abaxial to adaxial face of pinnae. The way in which these characters combine in the species is still in study, but have interest farther than the mere descriptive point of view, may be giving additional information both on the evolution of vascular organization and interspecific relationships.

Gametophytes, also studied here for the first time, are of the cordate, hairy type, previously reported for the Blechnaceae by Atkinson (1973). Germination belongs to the Vittaria type (Nayar and Kaur 1968) and subsequent gametophyte development follows the Aspidium pattern (Nayar and Kaur 1969), slightly deviating from the general model for the delayed formation of the first hair. The knowledge of the gametophytic generation is still scarce for neotropical species of Blechnum. Only B. buchtienii Rosenst. (Stokey and Atkinson 1952), B. hastatum Kaulf., B. magellanicum, B. microphyllum (Goldm.) C. V. Morton, $B$. mochaenum Kunkel and $B$. penna-marina (Rodríguez Ríos, 1973), B. cordatum [as B. chilense (Kaulf.) Mett.] and B. cycadifolium (Pérez García et al. 1996) were studied, and both hairy and naked types of gametophytes have been described. When it is known, the ontogeny of the gametangia start either with the arquegonia, as in B. sprucei, or with the antheridia.

\section{AKNOWLEDGMENTS}

This work was carried out at the Departamento de Biología Vegetal I, Facultad de Biología, Universidad Complutense de Madrid (España), and the Laboratorio de Anatomía Vegetal Evolutiva y Sistemática (LEAVES), Facultad de Ciencias Naturales y Museo de La Plata (Argentina). The support for an international Project came from the following Institutions: Agencia Española de Cooperación Internacional (Referencia AECI A8930/07), Consejo Nacional de Investigaciones Científicas y Técnicas de Buenos Aires (CONICET), and Universidad Nacional de La Plata (Argentina). One of the authors had the benefit of a Universidad Complutense - del Amo Grant to visit the herbarium UC at Berkeley, California.

\section{RESUMEN}

El helecho Blechnum sprucei crece en Mesoamérica (Costa Rica) y Sudamérica, desde Colombia a Bolivia, SE y centro de Brasil, Paraguay y Argentina. Es una especie característica, algo vulnerable y orófila. Se estudiaron caracteres exomorfológicos de especimenes provenientes de distintos puntos de su gran área de distribución. Adicionalmente, se llevó a cabo un detallado análisis de los modelos epidérmicos jóvenes y maduros, del indumento de la lámina y los ejes, y de la organización vascular en los estipes y costas. Se han estudiado por primera vez la morfología esporal, el desarrollo de los gametófitos, que resultaron cordados y pelosos, y su expresión sexual. Presenta esporófitos grandes, suberectos, con rizomas escamosos y frondas dimórficas, con estipes cortos y escamosos y láminas estériles de lanceoladas a elípticas. El raquis puede crecer indefinidamente como un eje radicante que multiplica las plantas vegetativamente. Las pinnas son lanceoladas, herbáceas, con márgenes crenados y papilosos, y la superficie escamosa y pelosa. Son pecioluladas, con venas libres y visibles, regularmente furcadas cerca de la costa, terminando en hidatodos grandes y activos. Las láminas fértiles son anchamente elípticas y portan pinnas distales; presentan tejido vegetativo reducido a la porción que soporta el indusio y el cenosoro continuo. Pueden presentar raquis indefinidos, pero no prolíferos. 
Palabras clave: Blechnum sprucei, anatomía, distribución, gametófito, morfología, expresión sexual, espora, taxonomía.

\section{REFERENCES}

Atkinson, L.R. 1973. The gametophyte and family relationships. J. Linn. Soc. Bot. 67: 73-90.

de la Sota, E.R. 1977. Flora de la Provincia de Jujuy, República Argentina. Pteridophyta. Instituto Nacional de Tecnología Agropecuaria, Buenos Aires, Argentina.

Dyer, A.F. 1979. The culture of fern gametophytes for experimental investigation, p. 253-305. In A.F. Dyer (ed.). The experimental biology of ferns. Academic, Londres, Reino Unido.

Edwards, M.E. \& J.H. Miller. 1972. Growth regulation by ethylene in fern gametophytes. III. Inhibition of spore germination. Amer. J. Bot. 59: 458-465.

Gurr, L. 1966. The rational uses of dyes in biology. Williams and Wilkins, Baltimore, EEUU.

Holmgren, P.K, N.H. Holmgren \& L. Barnett. 1990. Index Herbariorum, Part I: Herbaria of the World. New York Botanical Garden, Nueva York, EEUU.

Lellinger, D.B. 2002. A Modern Multilingual Glossary of taxonomic Pteridology. Pteridologia 3: 1-246.

Lellinger, D.B. \& W.C. Taylor. 1997. A classification of spore ornamentation in the Pteridophyta, p. 33-42. In J.M. Camus, M. Gibby \& R.J. Johns (eds.). Pteridology in Perspective. Royal Botanic Gardens, Kew, Reino Unido.

Moran, R.C. 1995. Blechnaceae, p. 325-333. In G. Davidse, M. Souza \& S. Knapp (eds.). Flora Mesoamericana I, Psilotaceae a Salviniaceae. Universidad Autónoma de México, Missouri Botanical Garden \& The Natural History Museum, Londres, Reino Unido.

Nayar, B.K. \& S. Kaur. 1968. Spore germination in homosporous ferns. J. Palynol. 4: 1-14.

Nayar, B.K. \& S. Kaur. 1969. Types of prothallial development in homosporous ferns. Phytomorphology 19: 171-188.

Oliveira Dittrich, V.A. 2005. Estudos taxonômicos no gênero Blechnum L. (Pteridophyta-Blechnaceae) para as regiões Sudeste e Sul do Brasil. Ph. D. Thesis, São Paulo, Brasil.
Passarelli, L.M. 2007. Estudios esporales en especies del grupo Blechnum penna-marina (BlechnaceaePteridophyta). Acta Bot. Malac. 32: 1-19.

Pérez-García, B., A. Mendoza \& M. Ricci. 1996. Morfogénesis de la fase sexual de Blechnum chilense y Blechnum cycadifolium (Pterophyta: Blechnaceae). Revista Biol. Trop. 44: 491-497.

Ponce, M.M. 1996. Catálogo de las plantas vasculares de la República Argentina, Parte I. Pteridophyta. Syst. Bot. Monogr. 60: 1-79.

Prabhakar, M. 2003. Structure, delimitation, nomenclature and classification of stomata. Acta Bot. Sin. 46: 242- 252 .

Prada, C., C.H. Rolleri \& L.M. Passarelli. 2008. Morfología, caracterización y distribución geográfica de Blechnum cordatum (Blechnaceae-Pteridophyta). Acta Bot. Malac. 33: 29-46.

Rodríguez Ríos, R. 1973. Morfología de los protalos y algunos esporófitos jóvenes de algunas especies chilenas de Blechnum (Polypodiaceae s. 1.). Gayana 22: $1-30$.

Rolleri, C.H. 2004. Revisión del género Danaea (Marattiaceae-Pteridophyta). Darwiniana 42: 217301.

Rolleri, C.H. \& C. Prada. 2006a. Catálogo comentado de las especies mesoamericanas y sudamericanas de Blechnum L. (Blechnaceae-Pteridophyta). Anales Jard. Bot. Madrid 63: 67-106.

Rolleri, C.H. \& C. Prada. 2006b. Revisión de los grupos de especies del género Blechnum (BlechnaceaePteridophyta): el grupo B. penna-marina. Acta Bot. Malac. 31: 7-50.

Rolleri, C.H., C. Prada \& L.M. Passarelli. 2008. Estudios morfológicos y taxonómicos en Blechnum (BlechnaceaePteridophyta): Blechnum tabulare y B. magellanicum. Anales Jard. Bot. Madrid 65(2), in press.

Stokey, A.G. \& L.R. Atkinson. 1952. The gametophyte of Blechnum spicant (L.) Wither. and B. buchtienii Rosenst. Phytomorphology 2: 9-15.

Tryon, R.M. \& R.G. Stolze. 1993. Pteridophyta of Peru. Part. 5: Aspleniaceae-Polypodiaceae. Fieldiana, Botany, new series 32: 54-70.

Tryon, R.M. \& A.F. Tryon. 1982. Ferns and allied pants with special reference to tropical America. Springer, Nueva York, EEUU. 